Article

\title{
The Epidemiology of Melioidosis and Its Association with Diabetes Mellitus: A Systematic Review and Meta-Analysis
}

\author{
Sukanta Chowdhury ${ }^{1, *(\mathbb{D})}$, Lovely Barai ${ }^{2} \mathbb{D}$, Samira Rahat Afroze ${ }^{2}$, Probir Kumar Ghosh ${ }^{1} \mathbb{D}$, Farhana Afroz ${ }^{2}$, \\ Habibur Rahman ${ }^{1}$, Sumon Ghosh ${ }^{1}$ (D), Muhammad Belal Hossain ${ }^{3}$, Mohammed Ziaur Rahman ${ }^{1}$ (D), \\ Pritimoy Das ${ }^{4}$ and Muhammad Abdur Rahim ${ }^{2}$
}

Citation: Chowdhury, S.; Barai, L.; Afroze, S.R.; Ghosh, P.K.; Afroz, F.; Rahman, H.; Ghosh, S.; Hossain, M.B.; Rahman, M.Z.; Das, P.; et al. The Epidemiology of Melioidosis and Its Association with Diabetes Mellitus: A Systematic Review and Meta-Analysis. Pathogens 2022, 11, 149. https://doi.org/10.3390/ pathogens11020149

Academic Editor: Andrew Taylor-Robinson

Received: 14 November 2021 Accepted: 18 January 2022 Published: 25 January 2022

Publisher's Note: MDPI stays neutral with regard to jurisdictional claims in published maps and institutional affiliations.

Copyright: (C) 2022 by the authors. Licensee MDPI, Basel, Switzerland. This article is an open access article distributed under the terms and conditions of the Creative Commons Attribution (CC BY) license (https:// creativecommons.org/licenses/by/ $4.0 /)$
1 International Centre for Diarrhoeal Disease Research, Bangladesh (icddr,b), Dhaka 1212, Bangladesh; probir@icddrb.org (P.K.G.); rahmanhabibur803.hr@gmail.com (H.R.); sumon.ghosh@icddrb.org (S.G.); mzrahman@icddrb.org (M.Z.R.)

2 Bangladesh Institute of Research and Rehabilitation in Diabetes, Endocrine and Metabolic Disorders (BIRDEM) General Hospital, Dhaka 1000, Bangladesh; barai_lovely@yahoo.com (L.B.); srafroze6@gmail.com (S.R.A.); lubna0408@gmail.com (F.A.); muradrahim23@yahoo.com (M.A.R.)

3 Department of Ecology \& Evolutionary Biology, The University of Tennessee, Knoxville, TN 37996, USA; belal.vetmed@gmail.com

4 School of Health, Federation University Australia, Ballarat, VIC 3353, Australia; pritimoydas@gmail.com

* Correspondence: sukanta@icddrb.org

\begin{abstract}
Melioidosis is an under-recognized fatal disease in humans, caused by the Gram-negative bacterium Burkholderia pseudomallei. Globally, more than 35,000 human melioidosis cases have been reported since 1911. Soil acts as the natural reservoir of B. pseudomallei. Humans may become infected by this pathogen through direct contact with contaminated soil and/or water. Melioidosis commonly occurs in patients with diabetes mellitus, who increase the occurrence of melioidosis in a population. We carried out a systematic review and meta-analysis to investigate to what extent diabetes mellitus affects the patient in getting melioidosis. We selected 39 articles for meta-analysis. This extensive review also provided the latest updates on the global distribution, clinical manifestation, preexisting underlying diseases, and risk factors of melioidosis. Diabetes mellitus was identified as the predominant predisposing factor for melioidosis in humans. The overall proportion of melioidosis cases having diabetes was 45.68\% (95\% CI: 44.8-46.57, $p<0.001)$. Patients with diabetes mellitus were three times more likely to develop melioidosis than patients with no diabetes (RR 3.40, 95\% CI: $2.92-3.87, p<0.001)$. The other potential risk factors included old age, exposure to soil and water, preexisting underlying diseases (chronic kidney disease, lung disease, heart disease, and thalassemia), and agricultural activities. Evidence-based clinical practice guidelines for melioidosis in patients with diabetes mellitus may be developed and shared with healthcare professionals of melioidosis endemic countries to reduce morbidity.
\end{abstract}

Keywords: melioidosis; diabetes mellitus; humans; systematic review; meta-analysis

\section{Introduction}

Melioidosis is an infectious disease in humans caused by the soil-borne, Gramnegative, facultative, intracellular bacterium Burkholderia pseudomallei [1]. Melioidosis is endemic in Southeast Asia and Australia [1]. Soil is the natural reservoir of B. pseudomallei. The organism was isolated from soil and water from many countries including, Thailand, Malaysia, Australia, China, and Bangladesh [1,2]. The first few cases of melioidosis were reported from Myanmar in 1911 [3]. As of 19 July 2020, more than 35,000 human cases were reported globally [4]. The estimated incidence rate varies from country to country; 19.6 per 100,000 person-years in Australia and 12.7 per 100,000 person-years in Thailand [5].

Transmission of this organism occurs mainly by contact with contaminated soil and water through penetrating wounds or skin abrasions, and ulcers or burns [1]. Transmission 
through inhalation was also reported [6,7]. Farmers working in paddy fields are frequently exposed to B. pseudomallei-contaminated soil and water through skin inoculation $[1,5,8]$. The majority of the human cases were identified during the rainy season [5,9-12]. People of all age groups are susceptible, but adults with underlying conditions were mostly affected [5,13-16]. The major clinical presentations include localized abscesses, pneumonia, and acute septicaemia [17-24]. The case fatality rate (CFR) may reach up to $40 \%$ in untreated patients [17]. Many antibiotics, including ceftazidime, carbapenems (imipenem, meropenem), piperacillin, amoxicillin-clavulanate, ceftriaxone, and cefotaxime, showed various degrees of bactericidal activity [25-28]. Parenteral ceftazidime and meropenem are the choice of antibiotics to treat melioidosis and the duration of treatment for intensive therapy was recommended to be at least 14 days. The minimum treatment durations for melioidosis with central nervous system infection, osteomyelitis, and deep-seated abscess were eight, six and four weeks, respectively $[25,26]$. To prevent recrudescence or relapse of melioidosis, subsequent eradication therapy has been suggested. Oral trimethoprimsulfamethoxazole was preferred antibiotic for the subsequent eradication therapy and the duration of treatment was three to six months $[25,26]$. Parenteral amoxicillin-clavulanate was found effective for initial treatment, but not for severe melioidosis patients [25,29].

Reports from different countries showed that melioidosis was commonly detected in patients with diabetes mellitus [11,30-32]. In 2017, more than 450 million people suffered from diabetes mellitus globally, with approximately 5 million deaths [33]. People with diabetes mellitus increase the occurrence of melioidosis in a population [30]. It is still unclear why diabetic patients are at high risk of acquiring melioidosis, and hence, associated with more adverse outcomes and early death among these patients. Many review articles have been published to date on melioidosis, but no review article provided comprehensive information about the percentage of diabetics among melioidosis patients in a global perspective. The primary objective of this systematic review was to collect available information about the global distribution of melioidosis, clinical manifestation, microbiological and immunological characteristics, and risk factors of melioidosis in humans. Finally, we performed a meta-analysis to identify the relationship between melioidosis and diabetes mellitus.

\section{Methods}

\subsection{Search Strategy and Selection Criteria}

We performed a web-based in-depth literature search using four electronic databases: PubMed, PubMed Central, MEDLINE, and Google Scholar to identify full-text research articles, abstracts, case reports, and other relevant documents. Specific keywords "melioidosis" or "diabetes and melioidosis" or "Burkholderia pseudomallei" or "diabetes mellitus and Burkholderia pseudomallei" or "risk factors of melioidosis" were used to search relevant articles. We restricted our search to literature published in English only. All databases were searched from January to October 2021. We considered original articles, review articles, abstracts, and other relevant published documents. Publications from any country were included. Documents having one or more of the following criteria were excluded: (a) not relevant to the study question; (b) inadequate information; (c) duplicate data.

\subsection{Documents Selection for This Systematic Review and Meta-Analysis}

The extensive literature search revealed a total of 3156 publications. All selected documents were published between 1 January 1911 and 12 November 2021. Among these publications, we identified only 163 relevant documents that met the inclusion criteria (primary research studies). After initial screening, we performed a detailed review of selected published documents for data extraction that were relevant to our study. A total of 118 publications were identified for the full review (Figure 1). The first author thoroughly reviewed all selected articles, abstracts, and published documents for this systematic review. Finally, all extracted data were reviewed, organized, and revised based on feedback from all authors. 

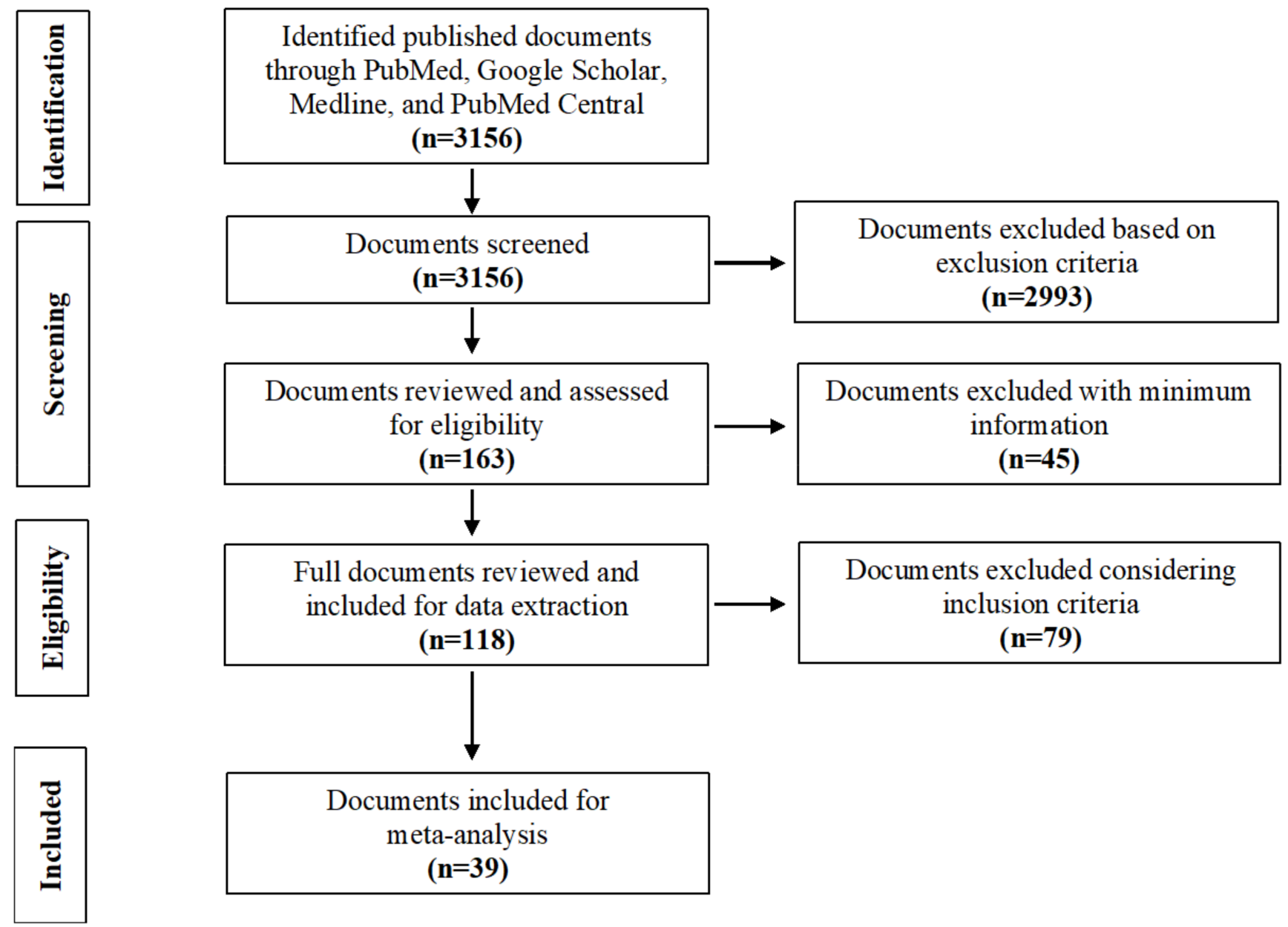

Figure 1. Flow diagram of the document search and selection.

To examine the association between melioidosis and diabetes mellitus, we selected 39 articles for meta-analysis using the following inclusion criteria: (a) the studies were published in peer-reviewed journals; (b) the studies reported melioidosis with diabetes mellitus status; (c) the studies reported at least five melioidosis cases having diabetes mellitus. We summarized the proportions of melioidosis having diabetes from the selected articles and logit transformed before calculating inverse variance-weighted averages described by Lipsey and Wilson [34]. The meta-analysis was performed for risk ratio (RR) with $95 \%$ confidence intervals to assess the overall association between melioidosis and diabetes mellitus. We used Python 3.6 version software to analyze the metadata and produce a global distribution map [35].

\section{Results and Discussion}

Globally, more than 50 countries reported at least one human case with B. pseudomallei infection (Figure 2, Supplementary Table S1) [4]. More than 35,000 human cases have been reported from 1911 to 2020 (Supplementary Table S1). Diabetes mellitus was identified by many studies as the predominant underlying risk factor associated with melioidosis in humans. This study provided the latest updates on the global distribution, clinical manifestation, microbiological and immunological characteristics, preexisting underlying diseases, and risk factors of melioidosis. The meta-analysis combined data from several studies throughout the world to identify the association between melioidosis and diabetes mellitus. 


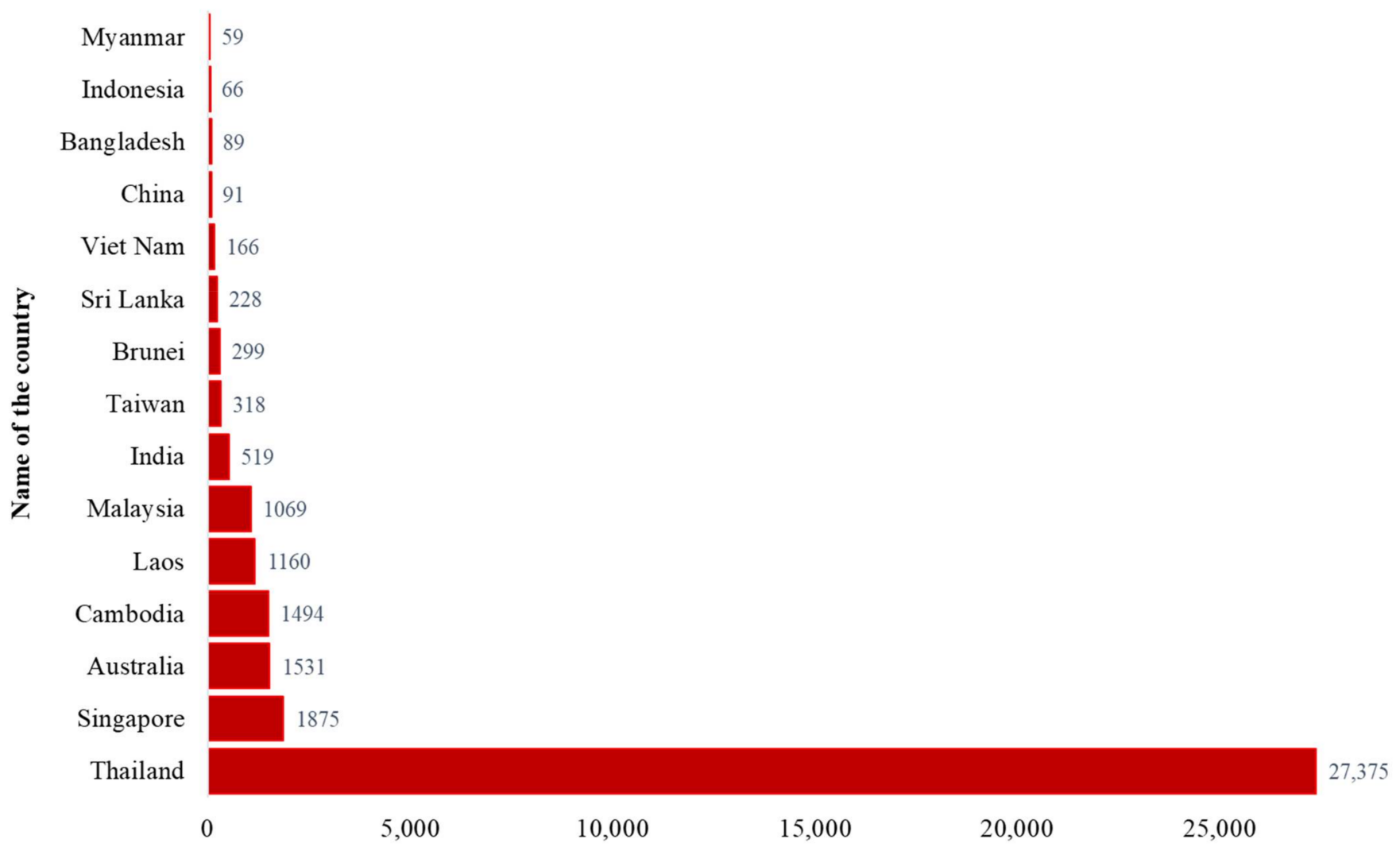

Figure 2. Top 15 countries reported more than 50 human melioidosis cases, 1911-2020 (Data source: Supplementary Table S1. Country data summary. Microbiology Department at Mahidol Oxford Tropical Medicine Research Unit. https: / / www.melioidosis.info/info.aspx?pageID=107\&contentID= 1070102, accessed on 16 May 2021) [4].

\subsection{Geographical Distribution of Melioidosis}

Melioidosis is endemic in tropical countries such as Southeast Asia, Northern Australia, India, Taiwan, and China (Figure 3). The distribution of human cases mainly depends on the exposure to B. pseudomallei in contaminated environments [36]. The CFR varied between countries $(8-60 \%)$ and the overall CFR was around $40 \%$ [37]. The highest number of reported human cases $(n=27,375)$ was in Thailand [4]. Most cases were detected from the North-Eastern provinces of Thailand and sepsis-related CFR was $40 \%$ [17,30]. Singapore reported more than 1800 cases with $16-48 \%$ CFR $[4,11,21,38,39]$. Malay and Indian populations living in Singapore were affected more than other groups of people [21]. The first human case was reported in Australia in 1950. So far, more than 1500 human cases have been reported and most patients were from the Northern Australia [1,4,40]. The reported CFR was 12\% ( $n=133)$ during 1989-2019 in Australia [40]. Cambodia, Laos and Malaysia reported more than 1000 cases of melioidosis in humans separately [4]. A hospital-based study from Cambodia reported $16.8 \%$ CFR among children with melioidosis [41]. India reported more than 500 cases and most of the cases were identified from the South-Western coastal Karnataka and northeastern Tamil Nadu [4,42,43]. A hospital-based observational study reported 23\% CFR in India [44]. Sri Lanka and Bangladesh reported more than 200 and 89 cases (including some unpublished cases; personal communication), respectively [4,45]. Other Southeast Asian countries outside of Thailand, such as Vietnam, Indonesia, Philippines, Brunei, and Myanmar also reported a significant number of melioidosis cases [4]. Taiwan, China, and Hong Kong reported 318, 91, 20 cases, respectively [4]. Although many other countries reported a number of B. pseudomallei infection in humans, the actual burden of this disease has not been properly recognized or was underestimated in most of the countries, because of poor diagnostic facilities, microbiological culture before the administration of antibiotics, and inadequate awareness among clinicians and 
microbiologists [4]. Countrywide instituting improved diagnostic capabilities with trained laboratory personals and surveillance can be helpful to detect melioidosis cases accurately.

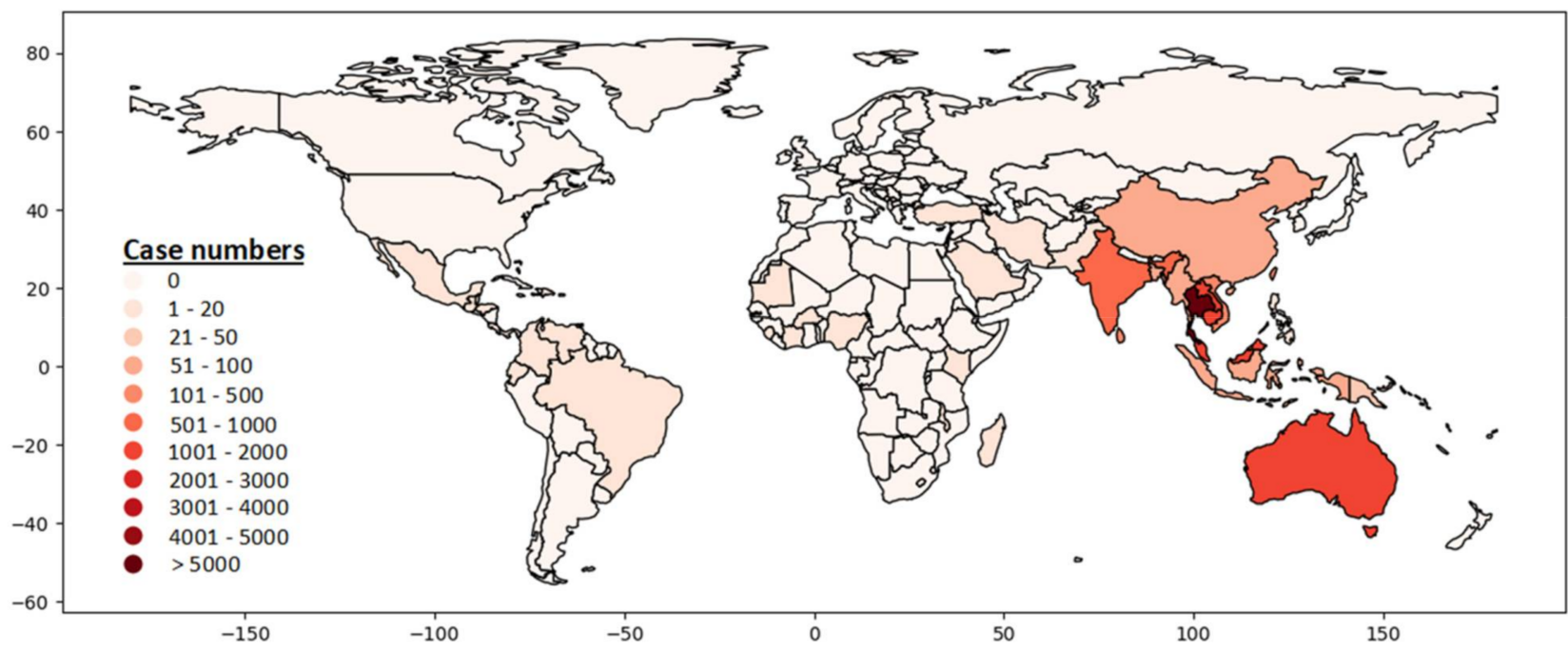

Figure 3. Global distribution of melioidosis in humans, 1911-2020 (Data source: (Supplementary Table S1. Country data summary. Microbiology Department at Mahidol Oxford Tropical Medicine Research Unit. https:/ / www.melioidosis.info/info.aspx?pageID=107\& contentID=1070102, accessed on 16 May 2021) [4].

\subsection{Clinical Presentations}

The clinical presentation of melioidosis reported by many countries was diverse. Septic shock was identified as the most fatal clinical presentation of melioidosis globally [46]. The other common clinical manifestations for melioidosis were fever, pneumonia, and abscess (Table 1). Multiple organs including, lung, liver, spleen, skeletal muscle, and prostate were mostly affected [17]. Other reported clinical manifestations were genitourinary infections, prostatic abscesses, splenic abscess, liver abscess, septic arthritis, hepatomegaly, splenomegaly, abdominal pain and joint pain were mostly commonly reported in Australia [13,15-17,19,20,42,45,47,48].

Table 1. Country wise reported clinical presentations for melioidosis in human.

\begin{tabular}{|c|c|c|}
\hline Country & Manifestation & References \\
\hline Australia & $\begin{array}{l}\text { Fever, pneumonia, genitourinary infections, abdominal pain, skin abscesses, } \\
\text { osteomyelitis, septic arthritis, soft tissue abscess, and encephalomyelitis, genitourinary } \\
\text { infection, communicating hydrocephalus and encephalomyelitis. }\end{array}$ & {$[15,31,40,49,50]$} \\
\hline Bangladesh & $\begin{array}{l}\text { Fever, abdominal pain, arthritis, cough, lung abscess, prostate abscess, liver abscess, } \\
\text { skin abscess, pneumonia, septic arthritis and meningitis. }\end{array}$ & {$[45,51,52]$} \\
\hline Cambodia & $\begin{array}{l}\text { Fever, cough, chest pain, weight loss, acute suppurativeparotitis, pneumonia, } \\
\text { Superficial soft-tissue abscess, Lymph-node abscess, Meningitis, Bone/joint infection, } \\
\text { Deep abscesses, urogenital infection, shock and multi-organ failure. }\end{array}$ & {$[13,41,53-55]$} \\
\hline China & $\begin{array}{l}\text { Fever, pneumonia, septicaemia, visceral abscess, urinary tract infection, } \\
\text { lymphadenitis, arthritis, parotitis, orchitis, soft tissue abscess and prostatic infection. }\end{array}$ & {$[12,16,56]$} \\
\hline India & $\begin{array}{l}\text { Fever, visceral abscess, septic arthritis, renal failure, abdominal pain, pneumonia, } \\
\text { hepatomegaly, osteo-myelitis, splenomegalyand septicemia. }\end{array}$ & {$[10,42,47,57]$} \\
\hline Laos & $\begin{array}{l}\text { Fever, weight loss, productive cough, acute bilateral supraclavicular lymphadenitis, } \\
\text { septic arthritis and spleen abscess. }\end{array}$ & {$[58,59]$} \\
\hline Malaysia & $\begin{array}{l}\text { Fever, pneumonia, septicemia, shock, lung abscess, cervical abscess, submandibular } \\
\text { abscess, axillary abscess, skin abscess, muscle abscess, liver abscess and brain abscess. }\end{array}$ & {$[18,22,60-62]$} \\
\hline
\end{tabular}


Table 1. Cont.

\begin{tabular}{cl}
\hline Country & \multicolumn{1}{c}{ Manifestation } \\
\hline Singapore & $\begin{array}{l}\text { Fever, pneumonia, acute respiratory distress syndrome (ARDS), abscess, abdominal } \\
\text { pain, vomiting, diarrhea, dysuria and haematuria. }\end{array}$ \\
\hline Taiwan & $\begin{array}{l}\text { Fever, cough, pneumonia, abdominal pain, septicemia, soft-tissue abscess, mycotic } \\
\text { aneurysm and renal failure. }\end{array}$ \\
\hline Thailand & $\begin{array}{l}\text { Fever, pneumonia, acute respiratory distress syndrome (ARDS), splenic abscess, liver } \\
\text { abscess, muscle abscess, prostatic abscesses, renal abscess, parotid gland abscess, } \\
\text { submandibular node abscess, septic arthritis, osteomyelitisand facial cellulitis. }\end{array}$ \\
\hline
\end{tabular}

The pattern of clinical manifestations was similar in children and adults. Children infected with B. pseudomallei in Thailand showed localized infections and pneumonia [64]. Children less than 15 years old were often diagnosed with cutaneous melioidosis in Australia [49]. Acute suppurative parotitis, pneumonia, and superficial soft-tissue abscess were the common clinical presentation in children in Cambodia, where parotitis is thought to be associated with ingestion of contaminated drinking water $[54,55,66]$. In Brazil, most of the children infected with B. pseudomallei had sepsis (90\%) and pneumonia (80\%) [67].

A number of melioidosis cases from Thailand, Australia and Laos showed recurrent infection [68-72]. In Thailand, 75\% of the episodes among 116 patients showed relapse (infection with same strain) and $25 \%$ of the episodes were due to re-infection (infection with a new strain) [68]. Among the recurrent cases in Thailand, localized infection was the most common manifestation followed by a bacteremic, disseminated and multifocal presentation [73]. In Australia, 39 (6\%) cases among the 679 survival patients were diagnosed with recurrent melioidosis during 1989-2012 [69].

\subsection{Microbiological and Immunological Characteristics}

B. pseudomallei is a motile, Gram-negative, oxidase positive rod mostly found in wet soils. B. pseudomallei has the ability to enter, survive, and replicate within host cells [74]. The cell surface of B. pseudomallei contains lipopolysaccharide (LPS), capsular polysaccharides and flagella that act as virulence factors [46]. Under aerobic conditions, the bacteria grow readily on routine culture media (blood and MacConkey agar) [75]. Ashdown's agar is used as selective media for improved isolation of B. pseudomallei from non-sterile sites [76]. B. pseudomallei is able to survive; absence of nutrients; an acidic environment $(\mathrm{pH}<4.5)$; wide temperature range $\left(24-32{ }^{\circ} \mathrm{C}\right)$; low water content soil [1]. The role of cellular adaptive immunity to B. pseudomallei has been reported. B. pseudomallei-specific CD4+ IFN- $\gamma$ T-cells and CD8+ IFN- $\gamma \mathrm{T}$-cells responses were depressed in fatal cases compared to melioidosis survivors $[77,78]$. B. pseudomallei also produces humoral immunity at any stage of infection, including subclinical infection. Immunoglobulin $\mathrm{G}(\operatorname{IgG}), \operatorname{Ig} \mathrm{A}$, and $\operatorname{IgM}$ were the common isotypes. Among the IgG isotypes, IgG1 and IgG2 subclasses were identified predominantly. Repeated exposure to $B$. pseudomallei produced a high-level antibody titre that might protect against severe infection [79-81]. A study identified a high level of B. pseudomalleispecific IgG2 among melioidosis survivors compared to non-survivors [82]. Focal or diffuse acute necrotizing inflammation with varying numbers of neutrophils, macrophages lymphocytes, and "giant cells" were observed in autopsy cases [83]. B. pseudomallei appeared to be resistant to serum bactericidal components. B. pseudomallei can survive and multiply within phagocytes, including macrophage/monocyte and neutrophil $[84,85]$. B. pseudomallei isolates were found sensitive to ceftazidime, cotrimoxazole, carbapenems (imipenem, meropenem), doxycycline and amoxicillin-clavulanate and resistance to ampicillin, aminoglycoside, ciprofloxacin, cefotaxime, and colistin $[10,25,44,57,86,87]$.

\subsection{Risk Factors Associated with Melioidosis}

Patients with certain medical conditions including diabetes mellitus, thalassemia, renal disease, chronic lung disease, and malignancy increase the risk of melioidosis 
(Table 2) [1,19,30,31,72,88-90]. Among the underlying diseases, diabetes mellitus was the main underlying risk factor for developing melioidosis, which was predominant in many countries where melioidosis was endemic (Figure 4, Supplementary Table S2). Agriculture farmers working mainly in paddy fields are considered a high-risk group because they are exposed to soil and water that could contain B. pseudomallei $[8,89,91,92]$.

Table 2. Country wise identified significant risk factors for melioidosis in humans.

\begin{tabular}{|c|c|c|}
\hline Country & Risk Factors & References \\
\hline \multirow{8}{*}{ Australia } & Diabetes mellitus & {$[15,31,90,93,94]$} \\
\hline & Exposure to soil and water & [49] \\
\hline & Alcoholism & {$[31,94]$} \\
\hline & Old age & {$[90]$} \\
\hline & Chronic lung disease & {$[31,90]$} \\
\hline & Chronic renal disease & {$[90]$} \\
\hline & Heart disease & [31] \\
\hline & Rainfall & [9] \\
\hline Bangladesh & Diabetes mellitus & [45] \\
\hline \multirow{3}{*}{ Cambodia } & Inappropriate antibiotic therapy & [13] \\
\hline & Close contact with wet soil & [89] \\
\hline & Underlying chronic disease & [89] \\
\hline \multirow{4}{*}{ India } & Diabetes mellitus & {$[10,42,95]$} \\
\hline & Alcoholism & [47] \\
\hline & Rainfall & [10] \\
\hline & Old age & [95] \\
\hline \multirow{2}{*}{ Malaysia } & Diabetes mellitus & [22] \\
\hline & Thalassemia (children) & [96] \\
\hline \multirow{2}{*}{ Singapore } & Diabetes mellitus & {$[11,38]$} \\
\hline & Old age & {$[11,38]$} \\
\hline \multirow{8}{*}{ Thailand } & Diabetes mellitus & {$[30,88]$} \\
\hline & Thalassaemia & [88] \\
\hline & Lung disease & [19] \\
\hline & Inappropriate antibiotic therapy & {$[19,65]$} \\
\hline & Working in rice field & [97] \\
\hline & Exposure to rain & [97] \\
\hline & Exposure to soil and water & [88] \\
\hline & Old age & [30] \\
\hline
\end{tabular}

In China, 50\% of melioidosis cases were reported among rural farmers [12]. In India, $37 \%$ of melioidosis patients had a history of soil exposure [95]. Rice farmers, gardeners, and planters were more likely to be infected with B. pseudomallei in Thailand [19,20]. In China, farming and freshwater fishing were mainly associated with melioidosis [16]. In Bangladesh, $36 \%$ of patients with melioidosis were agriculture farmers, and $88 \%$ of the cases had a history of soil contact or environmental exposure [45]. Most of the cases (77\%) from Cambodia had a history of close contact with soil and water [89].

Melioidosis was seasonal in the endemic countries. The majority of the melioidosis cases were detected during or shortly after the rainy season, which is consistent in Thailand, Australia, Singapore, India, China, Cambodia, and Bangladesh [8-11,13,91]. Moist clay soils favor the growth of B. pseudomallei [98]. It was perceived that farmers were more exposed to $B$. pseudomallei contaminated soil and flood water while working in the paddy fields during the monsoon [46]. Excessive alcohol consumption was observed to increase the risk of contracting melioidosis in Australia, Thailand, Cambodia, and India [15,31,40,89,90,99]. 


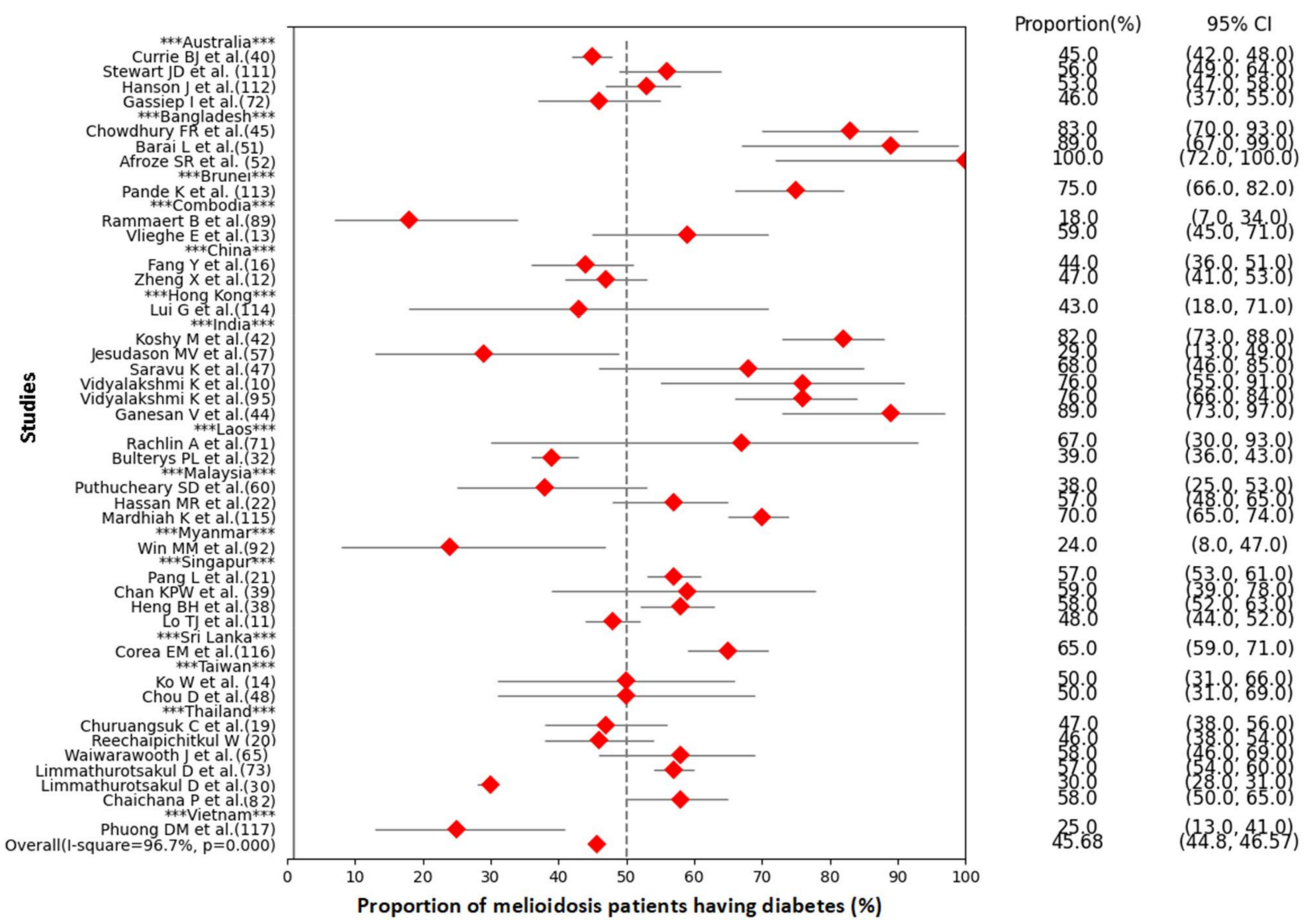

Figure 4. Forest plot of the meta-analysis on proportion of diabetes mellitus in melioidosis positive cases (Data source: Supplementary Table S2).

People of any age can be infected with B. pseudomallei, but the disease mostly occurred between 40-60 years [5]. The median age was 49 years in Thailand, 45 years in Bangladesh $[30,45]$. The mean age was 46 years in India, 47 years in Australia, 48 years in China, 49 years in Cambodia, 65 years in Taiwan, and 51 years in Singapore [13-16,21,42]. Melioidosis infections were also reported in children. In Cambodia, a hospital-based study reported 173 children with melioidosis from January 2009 to December 2013 and the median age was 5.7 years (range: 8 days- 15.9 years). The majority of the children cases were detected during the rainy season and $76 \%$ of them had localized infections [41]. Males were more likely to have melioidosis than females. The majority of the cases were male in India (92\%), Singapore (84\%), China (84\%), Bangladesh $(80 \%)$, Taiwan $(75 \%)$, Australia (75\%), Thailand (69\%), and Cambodia (59\%) [13,14,16,19,21,42,45].The gender differences in melioidosis prevalence particularly in adult people could occur due to frequent exposure to contaminated soil and water during agriculture.

Multiple studies reported recurrent melioidosis in Thailand, Australia, and Laos [69,71,100]. Two studies showed recurrent melioidosis infections in Thailand were associated with short duration (8-12 weeks or less) of oral antimicrobial therapy, whereas another study revealed oral antimicrobial therapy with 12-16 weeks was associated with the $90 \%$ decreased risk of relapse compared with less than 8 weeks therapy $[73,100,101]$.

\subsection{Diabetes Mellitus and Melioidosis}

Diabetes mellitus was identified as the major underlying disease for B. pseudomallei infection in India (81.6\%), Singapore (59.3\%), Malaysia (57\%), Australia (37\%), and Thailand $(30 \%)[15,22,30,42,102]$. Among the recurrent melioidosis cases, diabetes mellitus was also the most commonly identified underlying condition (57\%) [73]. 
The meta-analysis showed that the overall proportion of melioidosis patients having diabetes was $45.68 \%$ (95\% CI: 44.8-46.57, $p<0.001$ ) (Figure 4 ). The range of proportions among melioidosis patients having diabetes in different studies varied from $18 \%$ to $100 \%$. There was a significant heterogeneity across the studies (I-squared $=96.7 \%, p<0.001$ ). All studies included in the meta-analysis were hospital-based. Melioidosis cases were detected in both medical and intensive-care wards. Most melioidosis cases were diagnosed at various government tertiary hospitals, general hospitals, municipal hospitals, university teaching hospitals, private hospitals, and clinical laboratories. A small number of cases were identified at diabetic hospitals.

The forest plot generated from six studies showed that patients with diabetes were three times more likely to develop melioidosis than patients with no diabetes (RR 3.40, 95\% CI: $2.92-3.87$, I-squared $=98.2 \%, p<0.001$ ) (Figure 5). The range of RRs in six different studies varied from 1.5 (95\% CI: 1.04, 2.10) to 13.1 (95\% CI: 9.4, 18.1) (Supplementary Table S3).

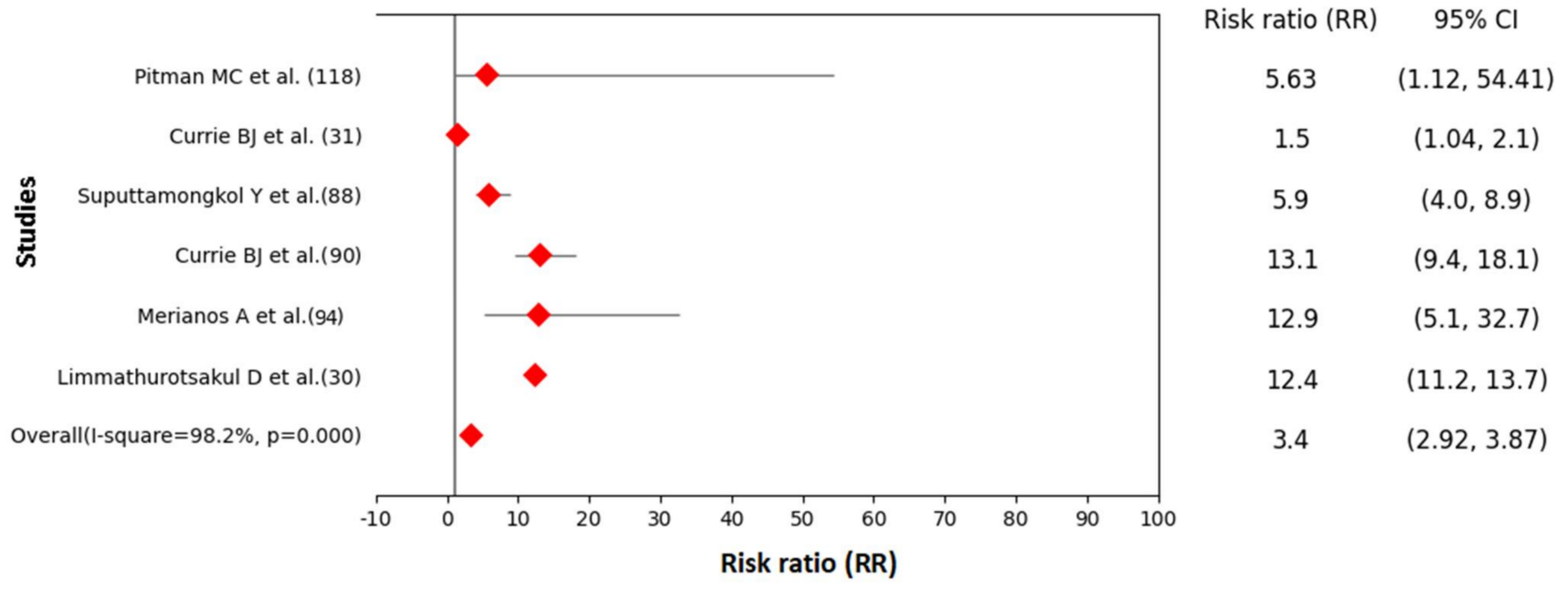

Figure 5. Forest plot showing association between melioidosis and diabetes mellitus in humans (Data source: Supplementary Table S3).

The occurrence of melioidosis with diabetes mellitus could be associated with the defective innate immunity of diabetic patients and poor glycaemic control. Acute melioidosis cases with diabetes mellitus showed depressed cellular adaptive immune response compared to melioidosis cases without diabetes mellitus. The mean IFN- $\gamma$ spot-forming cells (SFC) per million PBMC (Peripheral blood mononuclear cells) was 101 in acute melioidosis cases with diabetes. In contrast, the mean IFN- $\gamma$ SFC was 198 in acute melioidosis cases with no diabetes [77]. Some studies reported the relationship between poor glycaemic control and infectious diseases [103]. The significant association between higher hemoglobin $\mathrm{A}_{1 \mathrm{c}}\left(\mathrm{HbA}_{1 \mathrm{c}}\right)$ and increased infection was identified by a few studies [104,105]. Older patients with diabetes mellitus are at risk of getting an infection than younger group of people [106]. Better glycaemic control and better treatment compliance, particularly in melioidosis endemic countries, might reduce the infection.

Patients with diabetes mellitus are at increased risk for developing infections and sepsis [107]. Hyperglycaemia in diabetes is thought to cause abnormalities of the host immune response, particularly in neutrophil chemotaxis, adhesion, and intracellular killing. The polymorphonuclear neutrophil defects driven by diabetes mellitus may be responsible for increasing in susceptibility to melioidosis. Diabetic patients are thought to be less able to kill or inactivate $B$. pseudomallei that may be triggered due to impaired phagocytosis of B. pseudomallei, reduced migration in response to interleukin-8, and an inability to delay apoptosis/necrosis [108]. Phagocytosis of $B$. pseudomallei was significantly impaired among diabetic patients with very poor glycemic control $\left(\mathrm{HbA}_{1 \mathrm{c}}\right.$ level, $\left.>8.5 \%\right)$. The increased level of erythrocyte sedimentation rate (ESR), C-reactive protein (CRP), and leukocyte numbers 
were also observed in poorly controlled type 2 diabetic patients (Table 3) [52,109]. The presence of hyperglycemia in diabetes mellitus patients could play an important role for impaired phagocytic activity of neutrophils [110]. The increasing prevalence of diabetes mellitus with poor glycaemic control in melioidosis endemic countries might increase the burden of melioidosis over time.

Table 3. Biochemical and hematogical characteristics of the poorly controlled glycemia, wellcontrolled glycemia and non-diabetic patients [109].

\begin{tabular}{cccc}
\hline Characteristics & $\begin{array}{c}\text { Poorly-Controlled } \\
\text { Glycemia }\end{array}$ & $\begin{array}{c}\text { Well-Controlled } \\
\text { Glycemia }\end{array}$ & Non-Diabetic \\
\hline Glycated hemoglobin A1c $(\mathrm{HbA1c})(\%)$ & $10.1 \pm 1.2$ & $6.1 \pm 0.9$ & $5.1 \pm 0.4$ \\
\hline Erythrocyte sedimentation rate $(\mathrm{ESR})(\mathrm{mm} / \mathrm{h})$ & $32.8 \pm 18.4$ & $42.1 \pm 24$ & $10.7 \pm 7.6$ \\
\hline C-reactive protein $(\mathrm{CRP})(\mathrm{mg} / \mathrm{L})$ & $8.7 \pm 7.3$ & $7.0 \pm 5.2$ & $2.0 \pm 0.9$ \\
\hline Red blood cell count $(\mathrm{RBCC})\left(10^{12} / \mathrm{L}\right)$ & $4.9 \pm 0.6$ & $4.6 \pm 0.3$ & $4.8 \pm 0.5$ \\
\hline White blood cell count $(\mathrm{WBCC})\left(10^{9} / \mathrm{L}\right)$ & $8.05 \pm 2.5$ & $6.4 \pm 1.4$ & $1.8 \pm 1.1$ \\
\hline Lymphocytes $\left(10^{9} / \mathrm{L}\right)$ & $2.25 \pm 0.39$ & 0.48 \\
\hline Monocytes $\left(10^{9} / \mathrm{L}\right)$ & $0.59 \pm 0.21$ & $0.54 \pm 0.14$ & $3.45 \pm 0.11$ \\
\hline Neutrophils $\left(10^{9} / \mathrm{L}\right)$ & $4.86 \pm 2.2$ & $3.84 \pm 1.13$ & $3.04 \pm 0.72$ \\
\hline Platelets $\left(10^{9} / \mathrm{L}\right)$ & $270.8 \pm 91.7$ & $241.8 \pm 117.7$ & $236.5 \pm 47.7$ \\
\hline
\end{tabular}

\subsection{Other Comorbid Conditions and Melioidosis}

Renal disease was the second most underlying risk factor for melioidosis. Chronic lung disease and renal disease were reported in Australia $[15,31,90]$. In Thailand, melioidosis cases had a history of chronic renal failure, hematologic diseases, connective tissue diseases, chronic liver diseases, and tuberculosis [20,82]. In Singapore, 35.5\% of melioidosis had hypertension and $15.3 \%$ had renal impairment (15.3\%) [21]. Another study from Singapore reported that melioidosis patients had other underlying conditions such as tuberculosis, asthma, chronic obstructive pulmonary disease, and neoplasm [38]. In Cambodia, $1 \%$ of melioidosis patients had tuberculosis [53]. In India, 3.5\% of melioidosis patients had chronic kidney disease and 2.6\% had sickle cell disease [42]. In Malaysia, chronic renal failure and chronic lung disease associated with melioidosis were reported [22]. Thalassemia is identified as a significant risk factor for melioidosis in children in Malaysia [96]. In Taiwan, the majority of the melioidosis patients $(90 \%)$ had underlying conditions; chronic renal disease $(20 \%)$, malignancies $(13 \%)$, hypertension $(37 \%)$, coronary heart disease $(27 \%)$, cerebrovascular disease (20\%), and liver cirrhosis (13\%) [48]. Comorbidities were less commonly reported in children in Cambodia. Only a few children had thalassemia, chronic renal failure, probable acute lymphoblastic leukemia, and systemic lupus erythematosus [41].

\section{Conclusions and Recommendations}

This meta-analysis highlights a high prevalence of diabetes in patients with melioidosis and a significant association between melioidosis and diabetes mellitus. The poor glycaemic control of patients with diabetes mellitus raises significant concern about the morbidity of melioidosis. Our findings suggest that agriculture farmers having diabetes mellitus in melioidosis endemic areas should avoid direct contact with soil and water during the rainy season. Better glycaemic control might reduce the morbidity of melioidosis. More research works are needed to design and evaluate both pharmaceutical and behavior change interventions. Early treatment with appropriate antibiotics after its detection is crucial in improving patient outcomes and minimizing the severity. Evidence-based clinical practice and diagnostic guidelines for suspected melioidosis cases with diabetes mellitus should be urgently developed and shared with healthcare professionals and laboratory personnel in melioidosis endemic countries to reduce fatality. 
Supplementary Materials: The following supporting information can be downloaded at: https: / / www.mdpi.com/article/10.3390/pathogens11020149/s1, Table S1: Country wise reported melioidosis cases, 1911-2020; Table S2: Country with reported melioidosis cases having diabetes mellitus; Table S3: Association between diabetes mellitus and melioidosis. References [111-118] are cited in the supplementary materials.

Author Contributions: S.C. conceptualized the content of the article. L.B., S.R.A., P.K.G., F.A., H.R., S.G., M.B.H., M.Z.R., P.D. and M.A.R. contributed to writing and revision of the work. All authors have read and agreed to the published version of the manuscript.

Funding: No funding is required for this study.

Institutional Review Board Statement: This systematic review paper used previously published information from original studies that had already received proper institutional review board approval.

Informed Consent Statement: Not applicable.

Data Availability Statement: All data are available from the corresponding author after reasonable request.

Acknowledgments: This work was made possible by the generous support of the International Centre for Diarrheal Diseases Research, Bangladesh (icddr,b). icddr,b gratefully acknowledges the following donors who provide unrestricted support: Governments of Bangladesh, Canada, Sweden, and the UK.

Conflicts of Interest: The authors declare no conflict of interests.

\section{References}

1. Cheng, A.C.; Currie, B.J. Melioidosis: Epidemiology, pathophysiology, and management. Clin. Microbiol. Rev. 2005, 18, 383-416. [CrossRef] [PubMed]

2. Jilani, M.S.A.; Robayet, J.A.M.; Mohiuddin, M.; Hasan, M.R.; Ahsan, C.R.; Haq, J.A. Burkholderia pseudomallei: Its Detection in Soil and Seroprevalence in Bangladesh. PLoS Negl. Trop. Dis. 2016, 10, e004301. [CrossRef]

3. Whitmore, A. An account of a glanders-like disease occurring in Rangoon. Epidemiol. Infect. 1913, 13, 1-34. [CrossRef] [PubMed]

4. MORU. Reported Melioidosis Cases. Country Data Summary. Microbiology Department at Mahidol Oxford Tropical Medicine Research Unit (MORU). 2021. Available online: https://www.melioidosis.info/info.aspx?pageID=107\&contentID=1070102 (accessed on 16 May 2021).

5. Limmathurotsakul, D.; Peacock, S.J. Melioidosis: A clinical overview. Br. Med. Bull. 2011, 99, 125-139. [CrossRef] [PubMed]

6. Chen, P.-S.; Chen, Y.-S.; Lin, H.-H.; Liu, P.-J.; Ni, W.-F.; Hsueh, P.-T.; Liang, S.-H.; Chen, C.; Chen, Y.-L. Airborne transmission of melioidosis to humans from environmental aerosols contaminated with B. pseudomallei. PLoS Negl. Trop. Dis. 2015, 9, e0003834. [CrossRef]

7. Amadasi, S.; Dal Zoppo, S.; Bonomini, A.; Bussi, A.; Pedroni, P.; Balestrieri, G.; Signorini, L.; Castelli, F. A case of melioidosis probably acquired by inhalation of dusts during a helicopter flight in a healthy traveler returning from Singapore. J. Travel Med. 2015, 22, 57-60. [CrossRef]

8. Chaowagul, W.; White, N.J.; Dance, D.A.; Wattanagoon, Y.; Naigowit, P.; Davis, T.M.; Looareesuwan, S.; Pitakwatchara, N. Melioidosis: A major cause of community-acquired septicemia in northeastern Thailand. J. Infect. Dis. 1989, 159, 890-899. [CrossRef]

9. Currie, B.J.; Jacups, S.P. Intensity of rainfall and severity of melioidosis, Australia. Emerg. Infect. Dis. 2003, 9, 1538. [CrossRef]

10. Vidyalakshmi, K.; Shrikala, B.; Bharathi, B.; Suchitra, U. Melioidosis: An under-diagnosed entity in western coastal India: A clinico-microbiological analysis. Indian J. Med. Microbiol. 2007, 25, 245. [CrossRef]

11. Lo, T.J.; Ang, L.W.; James, L.; Goh, K.T. Melioidosis in a tropical city state, Singapore. Emerg. Infect. Dis. 2009, 15, 1645. [CrossRef]

12. Zheng, X.; Xia, Q.; Xia, L.; Li, W. Endemic melioidosis in southern China: Past and present. Trop. Med. Infect. Dis. 2019, 4, 39. [CrossRef]

13. Vlieghe, E.; Kruy, L.; De Smet, B.; Kham, C.; Veng, C.H.; Phe, T.; Koole, O.; Thai, S.; Lynen, L.; Jacobs, J. Melioidosis, phnom penh, Cambodia. Emerg. Infect. Dis. 2011, 17, 1289. [CrossRef]

14. Ko, W.-C.; Cheung, B.M.-H.; Tang, H.-J.; Shih, H.-I.; Lau, Y.-J.; Wang, L.-R.; Chuang, Y.-C. Melioidosis outbreak after typhoon, southern Taiwan. Emerg. Infect. Dis. 2007, 13, 896. [CrossRef] [PubMed]

15. Currie, B.J.; Fisher, D.A.; Howard, D.M.; Burrow, J.N.; Lo, D.; Selva-nayagam, S.; Anstey, N.M.; Huffam, S.E.; Snelling, P.L.; Marks, P.J. Endemic melioidosis in tropical northern Australia: A 10-year prospective study and review of the literature. Clin. Infect. Dis. 2000, 31, 981-986. [CrossRef]

16. Fang, Y.; Chen, H.; Li, Y.-L.; Li, Q.; Ye, Z.-J.; Mao, X.-H. Melioidosis in Hainan, China: A restrospective study. Trans. R. Soc. Trop. Med. Hyg. 2015, 109, 636-642. [CrossRef]

17. White, N. Melioidosis. Lancet 2003, 361, 1715-1722. [CrossRef]

18. Puthucheary, S.D. Melioidosis in Malaysia. Med. J. Malays. 2009, 64, 266-274. 
19. Churuangsuk, C.; Chusri, S.; Hortiwakul, T.; Charernmak, B.; Silpapojakul, K. Characteristics, clinical outcomes and factors influencing mortality of patients with melioidosis in southern Thailand: A 10-year retrospective study. Asian Pac. J. Trop. Med. 2016, 9, 256-260. [CrossRef] [PubMed]

20. Reechaipichitkul, W. Clinical manifestation of pulmonary melioidosis in adults. Southeast Asian J. Trop. Med. Public Health 2004, 35, 664-669. [PubMed]

21. Pang, L.; Harris, P.N.; Seiler, R.L.; Ooi, P.L.; Cutter, J.; Goh, K.T.; Cook, A.R.; Fisher, D.; Chai, L.Y.A. Melioidosis, Singapore, 2003-2014. Emerg. Infect. Dis. 2018, 24, 140. [CrossRef]

22. Hassan, M.R.; Pani, S.P.; Peng, N.P.; Voralu, K.; Vijayalakshmi, N.; Mehanderkar, R.; Aziz, N.A.; Michael, E. Incidence, risk factors and clinical epidemiology of melioidosis: A complex socio-ecological emerging infectious disease in the Alor Setar region of Kedah, Malaysia. BMC Infect. Dis. 2010, 10, 302. [CrossRef]

23. Chierakul, W.; Winothai, W.; Wattanawaitunechai, C.; Wuthiekanun, V.; Rugtaengan, T.; Rattanalertnavee, J.; Jitpratoom, P.; Chaowagul, W.; Singhasivanon, P.; White, N.J. Melioidosis in 6 tsunami survivors in southern Thailand. Clin. Infect. Dis. 2005, 41, 982-990. [CrossRef]

24. Ngauy, V.; Lemeshev, Y.; Sadkowski, L.; Crawford, G. Cutaneous melioidosis in a man who was taken as a prisoner of war by the Japanese during World War II. J. Clin. Microbiol. 2005, 43, 970-972. [CrossRef]

25. Dance, D. Treatment and prophylaxis of melioidosis. Int. J. Antimicrob. Agents 2014, 43, 310-318. [CrossRef]

26. Currie, B.J. Melioidosis: Evolving concepts in epidemiology, pathogenesis, and treatment in Seminars in respiratory and critical care medicine. Semin. Respir. Crit. Care Med. 2015, 36, 111-125.

27. Dance, D.; Wuthiekanun, V.; Chaowagul, W.; White, N. The antimicrobial susceptibility of Pseudomonas pseudomallei. Emergence of resistance in vitro and during treatment. J. Antimicrob. Chemother. 1989, 24, 295-309. [CrossRef]

28. Lipsitz, R.; Garges, S.; Aurigemma, R.; Baccam, P.; Blaney, D.D.; Cheng, A.C.; Currie, B.J.; Dance, D.; Gee, J.E.; Larsen, J. Workshop on treatment of and postexposure prophylaxis for Burkholderia pseudomallei and B. mallei infection, 2010. Emerg. Infect. Dis. 2012, 18, e2. [CrossRef]

29. Suputtamongkol, Y.; Rajchanuwong, A.; Chaowagul, W.; Dance, D.; Smith, M.; Wuthiekanun, V.; Walsh, A.; Pukrittayakamee, S.; White, N. Ceftazidime vs. amoxicillin/clavulanate in the treatment of severe melioidosis. Clin. Infect. Dis. 1994, 19, 846-853. [CrossRef]

30. Limmathurotsakul, D.; Wongratanacheewin, S.; Teerawattanasook, N.; Wongsuvan, G.; Chaisuksant, S.; Chetchotisakd, P.; Chaowagul, W.; Day, N.P.; Peacock, S.J. Increasing incidence of human melioidosis in Northeast Thailand. Am. J. Trop. Med. Hyg. 2010, 82, 1113-1117. [CrossRef]

31. Currie, B.J.; Ward, L.; Cheng, A.C. The epidemiology and clinical spectrum of melioidosis: 540 cases from the 20 year Darwin prospective study. PLoS Negl. Trop. Dis. 2010, 4, e900. [CrossRef]

32. Bulterys, P.L.; Bulterys, M.A.; Phommasone, K.; Luangraj, M.; Mayxay, M.; Kloprogge, S.; Miliya, T.; Vongsouvath, M.; Newton, P.N.; Phetsouvanh, R. Climatic drivers of melioidosis in Laos and Cambodia: A 16-year case series analysis. Lancet Planet. Health 2018, 2, e334-e343. [CrossRef]

33. Cho, N.; Shaw, J.; Karuranga, S.; Huang, Y.; da Rocha Fernandes, J.; Ohlrogge, A.; Malanda, B. IDF Diabetes Atlas: Global estimates of diabetes prevalence for 2017 and projections for 2045. Diabetes Res. Clin. Pract. 2018, 138, 271-281. [CrossRef] [PubMed]

34. Lipsey, M.W.; Wilson, D.B. Practical Meta-Analysis; SAGE Publications, Inc.: Thousand Oaks, CA, USA, 2001.

35. Caprioli, A.; Morabito, S.; Brugère, H.; Oswald, E. Enterohaemorrhagic Escherichia coli: Emerging issues on virulence and modes of transmission. Vet. Res. 2005, 36, 289-311. [CrossRef] [PubMed]

36. Currie, B.J.; Dance, D.A.; Cheng, A.C. The global distribution of Burkholderia pseudomallei and melioidosis: An update. Trans. R. Soc. Trop. Med. Hyg. 2008, 102, S1-S4. [CrossRef]

37. Fong, J.H.; Pillai, N.; Yap, C.G.; Jahan, N.K. Incidences, Case Fatality Rates and Epidemiology of Melioidosis Worldwide: A Review Paper. Open Access Libr. J. 2021, 8, 1-20. [CrossRef]

38. Heng, B.; Goh, K.; Yap, E.; Yeo, M. Epidemiological surveillance of melioidosis in Singapore. Ann.-Acad. Med. Singap. 1998, 27, 478-484. [PubMed]

39. Chan, K.P.; Low, J.G.; Raghuram, J.; Fook-Chong, S.M.; Kurup, A. Clinical characteristics and outcome of severe melioidosis requiring intensive care. Chest 2005, 128, 3674-3678. [CrossRef]

40. Currie, B.J.; Mayo, M.; Ward, L.M.; Kaestli, M.; Meumann, E.M.; Webb, J.R.; Woerle, C.; Baird, R.W.; Price, R.N.; Marshall, C.S. The Darwin Prospective Melioidosis Study: A 30-year prospective, observational investigation. Lancet Infect. Dis. 2021, 21, 1737-1746. [CrossRef]

41. Turner, P.; Kloprogge, S.; Miliya, T.; Soeng, S.; Tan, P.; Sar, P.; Yos, P.; Moore, C.E.; Wuthiekanun, V.; Limmathurotsakul, D. A retrospective analysis of melioidosis in Cambodian children, 2009-2013. BMC Infect. Dis. 2016, 16, 688. [CrossRef]

42. Koshy, M.; Jagannati, M.; Ralph, R.; Victor, P.; David, T.; Sathyendra, S.; Veeraraghavan, B.; Varghese, G.M. Clinical manifestations, antimicrobial drug susceptibility patterns, and outcomes in melioidosis cases, India. Emerg. Infect. Dis. 2019, 25, 316. [CrossRef]

43. Mukhopadhyay, C.; Shaw, T.; Varghese, G.M.; Dance, D.A. Melioidosis in South Asia (India, Nepal, Pakistan, Bhutan and Afghanistan). Trop. Med. Infect. Dis. 2018, 3, 51. [CrossRef]

44. Ganesan, V.; Murugan, M.; Sundaramurthy, R.; Soundaram, G.V. Melioidosis in a Tertiary Care Center from South India: A 5-year Experience. Indian J. Crit. Care Med. Peer-Rev. Off. Publ. Indian Soc. Crit. Care Med. 2021, 25, 327. [CrossRef] 
45. Chowdhury, F.R.; Jilani, M.S.A. Melioidosis in Bangladesh: A Clinical and Epidemiological Analysis of Culture-Confirmed Cases. Trop. Med. Infect. Dis. 2018, 3, 40. [CrossRef]

46. Wiersinga, W.J.; Van der Poll, T.; White, N.J.; Day, N.P.; Peacock, S.J. Melioidosis: Insights into the pathogenicity of Burkholderia pseudomallei. Nat. Rev. Microbiol. 2006, 4, 272-282. [CrossRef]

47. Saravu, K.; Mukhopadhyay, C.; Vishwanath, S.; Valsalan, R.; Docherla, M.; Vandana, K.; Shastry, B.; Bairy, I.; Rao, S. Melioidosis in southern India: Epidemiological and clinical profile. Southeast Asian J. Trop. Med. Public Health 2010, 41, 401-409. [PubMed]

48. Chou, D.-W.; Chung, K.-M.; Chen, C.-H.; Cheung, B.M.-H. Bacteremic melioidosis in southern Taiwan: Clinical characteristics and outcome. J. Formos. Med. Assoc. 2007, 106, 1013-1022. [CrossRef]

49. Gibney, K.B.; Cheng, A.C.; Currie, B.J. Cutaneous melioidosis in the tropical top end of Australia: A prospective study and review of the literature. Clin. Infect. Dis. 2008, 47, 603-609. [CrossRef] [PubMed]

50. Kandasamy, Y.; Norton, R. Paediatric melioidosis in north Queensland, Australia. J. Paediatr. Child Health 2008, 44, 706-708. [CrossRef]

51. Barai, L.; Jilani, M.S.A.; Haq, J.A. Melioidosis case reports and review of cases recorded among Bangladeshi population from 1988-2014. Ibrahim Med. Coll. J. 2014, 8, 25-31. [CrossRef]

52. Afroze, S.R.; Haque, H.F.; Afroz, F.; Barai, L.; Rahim, M.A.; Haque, M.T.; Ahmed, J.U.; Ahmed, A.S.; Hossain, M.D.; Rahman, M.R. Socio-demographic, clinical and laboratory characteristics of melioidosis: Four-year experience of managing consecutive 11 cases in a tertiary care hospital of Bangladesh. BIRDEM Med. J. 2017, 7, 28-37. [CrossRef]

53. Pho, Y.; Nhem, S.; Sok, C.; Phann, D.; Nob, H.; Thann, S.; Yin, S.; Kim, C.; Letchford, J.; Fassier, T. Melioidosis in patients with suspected tuberculosis in Cambodia: A single-center cross-sectional study. Int. J. Tuberc. Lung Dis. 2018, 22, 1481-1485. [CrossRef]

54. Pagnarith, Y.; Kumar, V.; Thaipadungpanit, J.; Wuthiekanun, V.; Amornchai, P.; Sin, L.; Day, N.P.; Peacock, S.J. Emergence of pediatric melioidosis in Siem Reap, Cambodia. Am. J. Trop. Med. Hyg. 2010, 82, 1106-1112. [CrossRef]

55. Stoesser, N.; Pocock, J.; Moore, C.E.; Soeng, S.; Chhat, H.P.; Sar, P.; Limmathurotsakul, D.; Day, N.; Thy, V.; Sar, V. Pediatric Suppurative Parotitis in Cambodia 2007-2011. Pediatric Infect. Dis. J. 2012, 31, 865. [CrossRef]

56. Yang, S.; Tong, S.; Mo, C.; Jiang, Z.; Yang, S.; Ma, Y.; Lu, Z. Prevalence of human melioidosis on Hainan Island in China. Microbiol. Immunol. 1998, 42, 651-654. [CrossRef]

57. Jesudason, M.V.; Anbarasu, A.; Jacob John, T. Septicaemic melioidosis in a tertiary care hospital in south India. Indian J. Med. Res. 2003, 117, 119-121.

58. Yuan, Y.; Yao, Z.; Xiao, E.; Zhang, J.; Wang, B.; Ma, B.; Li, Y.; Yan, W.; Wang, S.; Ma, Q. The first imported case of melioidosis in a patient in Central China. Emerg. Microbes Infect. 2019, 8, 1223-1228. [CrossRef]

59. Phetsouvanh, R.; Phongmany, S.; Newton, P.; Mayxay, M.; Ramsay, A.; Wuthiekanun, V.; White, N.J. Melioidosis and Pandora's box in the Lao People's Democratic Republic. Clin. Infect. Dis. 2001, 32, 653-654. [CrossRef]

60. Puthucheary, S.; Parasakthi, N.; Lee, M. Septicaemic melioidosis: A review of 50 cases from Malaysia. Trans. R. Soc. Trop. Med. Hyg. 1992, 86, 683-685. [CrossRef]

61. Yee, K.; Lee, M.; Chua, C.; Puthucheary, S. Melioidosis, the great mimicker: A report of 10 cases from Malaysia. J. Trop. Med. Hyg. 1988, 91, 249-254.

62. How, S.; Ng, K.; Jamalludin, A.; Shah, A.; Rathor, Y. Melioidosis in Pahang, Malaysia. Med. J. Malays. $2005,60,606-613$.

63. Hsueh, P.-R.; Teng, L.-J.; Lee, L.-N.; Yu, C.-J.; Yang, P.-C.; Ho, S.-W.; Luh, K.-T. Melioidosis: An emerging infection in Taiwan? Emerg. Infect. Dis. 2001, 7, 428. [CrossRef]

64. Pongrithsukda, V.; Simakachorn, N.; Pimda, J. Childhood melioidosis in northeastern Thailand. Southeast Asian J. Trop. Med. Public Health 1988, 19, 309-316.

65. Waiwarawooth, J.; Jutiworakul, K.; Joraka, W. Epidemiology and clinical outcome of melioidosis at Chonburi Hospital, Thailand. J. Infect. Dis. Antimicrob. Agents 2008, 25, 1-11.

66. Chandna, A.; Bonhoeffer, M.; Miliya, T.; Suy, K.; Sao, S.; Turner, P. Improving Treatment and Outcomes for Melioidosis in Children, Northern Cambodia, 2009-2018. Emerg. Infect. Dis. 2021, 27, 1169. [CrossRef]

67. Lima, R.X.R.; Rolim, D.B. Melioidosis in Children, Brazil, 1989-2019. Emerg. Infect. Dis. 2021, 27, 1705. [CrossRef]

68. Maharjan, B.; Chantratita, N.; Vesaratchavest, M.; Cheng, A.; Wuthiekanun, V.; Chierakul, W.; Chaowagul, W.; Day, N.P.; Peacock, S.J. Recurrent melioidosis in patients in northeast Thailand is frequently due to reinfection rather than relapse. J. Clin. Microbiol. 2005, 43, 6032-6034. [CrossRef]

69. Sarovich, D.S.; Ward, L.; Price, E.P.; Mayo, M.; Pitman, M.C.; Baird, R.W.; Currie, B.J. Recurrent melioidosis in the Darwin Prospective Melioidosis Study: Improving therapies mean that relapse cases are now rare. J. Clin. Microbiol. 2014, 52, 650-653. [CrossRef]

70. Currie, B.J.; Fisher, D.A.; Anstey, N.M.; Jacups, S.P. Melioidosis: Acute and chronic disease, relapse and re-activation. Trans. R. Soc. Trop. Med. Hyg. 2000, 94, 301-304. [CrossRef]

71. Rachlin, A.; Dittrich, S.; Phommasone, K.; Douangnouvong, A.; Phetsouvanh, R.; Newton, P.N.; Dance, D.A. Investigation of recurrent melioidosis in Lao People's Democratic Republic by multilocus sequence typing. Am. J. Trop. Med. Hyg. 2016, 94, 1208-1211. [CrossRef]

72. Gassiep, I.; Ganeshalingam, V.; Chatfield, M.D.; Harris, P.N.; Norton, R.E. The epidemiology of melioidosis in Townsville, Australia. Trans. R. Soc. Trop. Med. Hyg. 2021, trab125. [CrossRef] 
73. Limmathurotsakul, D.; Chaowagul, W.; Chierakul, W.; Stepniewska, K.; Maharjan, B.; Wuthiekanun, V.; White, N.J.; Day, N.P.; Peacock, S.J. Risk factors for recurrent melioidosis in northeast Thailand. Clin. Infect. Dis. 2006, 43, 979-986. [CrossRef]

74. Adler, B. Strategies for intracellular survival of Burkholderia pseudomallei. Front. Microbiol. 2011, 2, 170.

75. Gassiep, I.; Armstrong, M.; Norton, R. Human melioidosis. Clin. Microbiol. Rev. 2020, 33, e00006-19. [CrossRef]

76. Wuthiekanun, V.; Dance, D.; Wattanagoon, Y.; Supputtamongkol, Y.; Chaowagul, W.; White, N. The use of selective media for the isolation of Pseudomonas pseudomallei in clinical practice. J. Med. Microbiol. 1990, 33, 121-126. [CrossRef]

77. Jenjaroen, K.; Chumseng, S.; Sumonwiriya, M.; Ariyaprasert, P.; Chantratita, N.; Sunyakumthorn, P.; Hongsuwan, M.; Wuthiekanun, V.; Fletcher, H.A.; Teparrukkul, P. T-cell responses are associated with survival in acute melioidosis patients. PLoS Negl. Trop. Dis. 2015, 9, e0004152. [CrossRef]

78. Nithichanon, A.; Rinchai, D.; Buddhisa, S.; Saenmuang, P.; Kewcharoenwong, C.; Kessler, B.; Khaenam, P.; Chetchotisakd, P.; Maillere, B.; Robinson, J. Immune control of Burkholderia pseudomallei-Common, high-Frequency T-cell responses to a Broad repertoire of immunoprevalent epitopes. Front. Immunol. 2018, 9, 484. [CrossRef] [PubMed]

79. Chenthamarakshan, V.; Vadivelu, J.; Puthucheary, S. Detection of immunoglobulins M and G using culture filtrate antigen of Burkholderia pseudomallei. Diagn. Microbiol. Infect. Dis. 2001, 39, 1-7. [CrossRef]

80. Vasu, C.; Vadivelu, J.; Puthucheary, S. The humoral immune response in melioidosis patients during therapy. Infection 2003, 31, 24-30. [CrossRef]

81. Chenthamarakshan, V.; Kumutha, M.; Vadivelu, J.; Puthucheary, S. Distribution of immunoglobulin classes and IgG subclasses against a culture filtrate antigen of Burkholderia pseudomallei in melioidosis patients. J. Med. Microbiol. 2001, 50, 55-61. [CrossRef]

82. Chaichana, P.; Jenjaroen, K.; Chumseng, S.; Sumonwiriya, M.; Rongkard, P.; Kronsteiner, B.; Teparrukkul, P.; Limmathurotsakul, D.; Day, N.P.; Chantratita, N. Role of Burkholderia pseudomallei-Specific IgG2 in Adults with Acute Melioidosis, Thailand. Emerg. Infect. Dis. 2021, 27, 463. [CrossRef] [PubMed]

83. Wong, K.; Puthucheary, S.; Vadivelu, J. The histopathology of human melioidosis. Histopathology 1995, 26, 51-55. [CrossRef]

84. Ismail, G.; Razak, N.; Mohamed, R.; Embi, N.; Omar, O. Resistance of Pseudomonas pseudomallei to normal human serum bactericidal action. Microbiol. Immunol. 1988, 32, 645-652. [CrossRef]

85. Jones, A.L.; Beveridge, T.J.; Woods, D.E. Intracellular survival of Burkholderia pseudomallei. Infect. Immun. 1996, 64, 782-790. [CrossRef]

86. Dutta, S.; Haq, S.; Hasan, M.R.; Haq, J.A. Antimicrobial susceptibility pattern of clinical isolates of Burkholderia pseudomallei in Bangladesh. BMC Res. Notes 2017, 10, 299. [CrossRef]

87. Trinh, T.; Hoang, T.; Tran, D.; Trinh, V.; Göhler, A.; Nguyen, T.; Hoang, S.; Krumkamp, R.; Nguyen, L.; May, J. A simple laboratory algorithm for diagnosis of melioidosis in resource-constrained areas: A study from north-central Vietnam. Clin. Microbiol. Infect. 2018, 24, e81-e84. [CrossRef]

88. Suputtamongkol, Y.; Chaowagul, W.; Chetchotisakd, P.; Lertpatanasuwun, N.; Intaranongpai, S.; Ruchutrakool, T.; Budhsarawong, D.; Mootsikapun, P.; Wuthiekanun, V.; Teerawatasook, N. Risk factors for melioidosis and bacteremic melioidosis. Clin. Infect. Dis. 1999, 29, 408-413. [CrossRef]

89. Rammaert, B.; Beauté, J.; Borand, L.; Hem, S.; Buchy, P.; Goyet, S.; Overtoom, R.; Angebault, C.; Te, V.; Try, P.L. Pulmonary melioidosis in Cambodia: A prospective study. BMC Infect. Dis. 2011, 11, 126. [CrossRef]

90. Currie, B.J.; Jacups, S.P.; Cheng, A.C.; Fisher, D.A.; Anstey, N.M.; Huffam, S.E.; Krause, V.L. Melioidosis epidemiology and risk factors from a prospective whole-population study in northern Australia. Trop. Med. Int. Health 2004, 9, 1167-1174. [CrossRef]

91. Suputtamongkol, Y.; Hall, A.; Dance, D.; Chaowagul, W.; Rajchanuvong, A.; Smith, M.; White, N. The epidemiology of melioidosis in Ubon Ratchatani, northeast Thailand. Int. J. Epidemiol. 1994, 23, 1082-1090. [CrossRef]

92. Win, M.M.; Win, K.K.N.; Wah, T.T.; Aye, S.N.; Htwe, T.T.; Zin, K.N.; Aung, M.T.; Aung, W.W.; Ashley, E.A.; Smithuis, F. Enhanced melioidosis surveillance in patients attending four tertiary hospitals in Yangon, Myanmar. Epidemiol. Infect. 2021, 149 , e154. [CrossRef]

93. Malczewski, A.B.; Oman, K.M.; Norton, R.E.; Ketheesan, N. Clinical presentation of melioidosis in Queensland, Australia. Trans. R. Soc. Trop. Med. Hyg. 2005, 99, 856-860. [CrossRef]

94. Merianos, A.; Patel, M.; Lane, J.; Noonan, C.; Sharrock, D.; Mock, P.; Currie, B. The 1990-1991 outbreak of melioidosis in the Northern Territory of Australia: Epidemiology and environmental studies. Southeast Asian J. Trop. Med. Public Health 1993, 24, 425-435.

95. Vidyalakshmi, K.; Lipika, S.; Vishal, S.; Damodar, S.; Chakrapani, M. Emerging clinico-epidemiological trends in melioidosis: Analysis of 95 cases from western coastal India. Int. J. Infect. Dis. 2012, 16, e491-e497. [CrossRef]

96. Fong, S.M.; Wong, K.J.; Fukushima, M.; Yeo, T.W. Thalassemia major is a major risk factor for pediatric melioidosis in Kota Kinabalu, Sabah, Malaysia. Clin. Infect. Dis. 2015, 60, 1802-1807. [CrossRef]

97. Limmathurotsakul, D.; Kanoksil, M.; Wuthiekanun, V.; Kitphati, R.; deStavola, B.; Day, N.P.; Peacock, S.J. Activities of daily living associated with acquisition of melioidosis in northeast Thailand: A matched case-control study. PLoS Negl. Trop. Dis. 2013, 7, e2072 [CrossRef]

98. Thomas, A.; Forbes-Faulkner, J.; Parker, M. Isolation of Pseudomonas pseudomallei from clay layers at defined depths. Am. J. Epidemiol. 1979, 110, 515-521. [CrossRef] 
99. Gassiep, I.; Armstrong, M.; Norton, R. Identification of Burkholderia pseudomallei by use of the Vitek mass spectrometer. J. Clin. Microbiol. 2019, 57, e00081-19. [CrossRef]

100. Chaowagul, W.; Suputtamongkol, Y.; Dance, D.; Rajchanuvong, A.; White, N. Relapse in melioidosis: Incidence and risk factors. J. Infect. Dis. 1993, 168, 1181-1185.

101. Chaowagul, W.; Chierakul, W.; Simpson, A.J.; Short, J.M.; Stepniewska, K.; Maharjan, B.; Rajchanuvong, A.; Busarawong, D.; Limmathurotsakul, D.; Cheng, A.C. Open-label randomized trial of oral trimethoprim-sulfamethoxazole, doxycycline, and chloramphenicol compared with trimethoprim-sulfamethoxazole and doxycycline for maintenance therapy of melioidosis. Antimicrob. Agents Chemother. 2005, 49, 4020-4025. [CrossRef]

102. Currie, B.; Howard, D.; Nguyen, V.T.; Withnall, K.; Merianos, A. The 1990-1991 outbreak of melioidosis in the Northern Territory of Australia: Clinical aspects. Southeast Asian J. Trop. Med. Public Health 1993, 24, 436-443.

103. Pearson-Stuttard, J.; Blundell, S.; Harris, T.; Cook, D.G.; Critchley, J. Diabetes and infection: Assessing the association with glycaemic control in population-based studies. Lancet Diabetes Endocrinol. 2016, 4, 148-158. [CrossRef]

104. Hirji, I.; Guo, Z.; Andersson, S.W.; Hammar, N.; Gomez-Caminero, A. Incidence of urinary tract infection among patients with type 2 diabetes in the UK General Practice Research Database (GPRD). J. Diabetes Its Complicat. 2012, 26, 513-516. [CrossRef]

105. Tessier, D.M. Optimal glycemic control in the elderly: Where is the evidence and who should be targeted? Aging Health 2011, 7, 89-96. [CrossRef]

106. McDonald, H.; Nitsch, D.; Millett, E.; Sinclair, A.; Thomas, S. New estimates of the burden of acute community-acquired infections among older people with diabetes mellitus: A retrospective cohort study using linked electronic health records. Diabet. Med. 2014, 31, 606-614. [CrossRef] [PubMed]

107. Muller, L.; Gorter, K.; Hak, E.; Goudzwaard, W.; Schellevis, F.; Hoepelman, A.; Rutten, G. Increased risk of common infections in patients with type 1 and type 2 diabetes mellitus. Clin. Infect. Dis. 2005, 41, 281-288. [CrossRef]

108. Chanchamroen, S.; Kewcharoenwong, C.; Susaengrat, W.; Ato, M.; Lertmemongkolchai, G. Human polymorphonuclear neutrophil responses to Burkholderia pseudomallei in healthy and diabetic subjects. Infect. Immun. 2009, 77, 456-463. [CrossRef]

109. Morris, J.; Williams, N.; Rush, C.; Govan, B.; Sangla, K.; Norton, R.; Ketheesan, N. Burkholderia pseudomallei triggers altered inflammatory profiles in a whole-blood model of type 2 diabetes-melioidosis comorbidity. Infect. Immun. 2012, 80, 2089-2099. [CrossRef]

110. Lecube, A.; Pachón, G.; Petriz, J.; Hernández, C.; Simó, R. Phagocytic activity is impaired in type 2 diabetes mellitus and increases after metabolic improvement. PLoS ONE 2011, 6, e23366. [CrossRef] [PubMed]

111. Stewart, J.; Smith, S.; Binotto, E.; McBride, W.; Currie, B.J.; Hanson, J. The epidemiology and clinical features of melioidosis in Far North Queensland: Implications for patient management. PLoS Neglected Trop. Dis. 2017, 11, e0005411. [CrossRef]

112. Hanson, J.; Smith, S.; Stewart, J.; Horne, P.; Ramsamy, N. Melioidosis-a disease of socioeconomic disadvantage. PLoS Negl. Trop. Dis. 2021, 15, e0009544. [CrossRef] [PubMed]

113. Pande, K.; Abd Kadir, K.A.; Asli, R.; Chong, V.H. Melioidosis in Brunei Darussalam. Trop. Med. Infect. Diseas. 2018, 3, 20. [CrossRef] [PubMed]

114. Lui, G.; Tam, A.; Tso, E.Y.; Wu, A.K.; Zee, J.; Choi, K.W.; Lam, W.; Chan, M.C.; Ting, W.M.; Hung, I.F. Melioidosis in Hong Kong. Trop. Med. Infect. Dis. 2018, 3, 91. [CrossRef]

115. Mardhiah, K.; Wan-Arfah, N.; Naing, N.N.; Hassan, M.R.A.; Chan, H.K. The Cox model of predicting mortality among melioidosis patients in Northern Malaysia: A retrospective study. Medicine 2021, 100, e26160. [CrossRef]

116. Corea, E.M.; de Silva, A.D.; Thevanesam, V. Melioidosis in Sri Lanka. Trop. Med. Infect. Dis. 2018, 3, 22. [CrossRef] [PubMed]

117. Phuong, D.M.; Trung, T.T.; Breitbach, K.; Tuan, N.Q.; Nübel, U.; Flunker, G.; Khang, D.D.; Quang, N.X.; Steinmetz, I. WITHDRAWN: Clinical and microbiological features of melioidosis in northern Vietnam. Trans. R. Soc. Trop. Med. Hyg. 2008, 102, S30-S36. [CrossRef]

118. Pitman, M.; Luck, T.; Marshall, C.S.; Anstey, N.M.; Ward, L.; Currie, B.J. Intravenous Therapy Duration and Outcomes in Melioidosis: A New Treatment Paradigm. PLOS Neglected Trop. Dis. 2015, 9, e0003586. [CrossRef] 